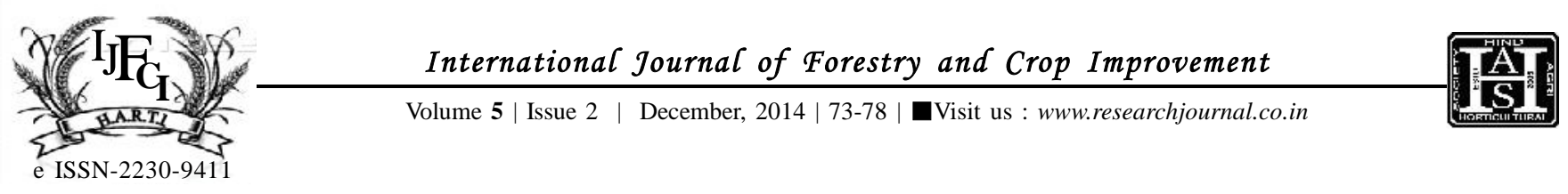

\title{
Effect of new post emergence herbicides on yield and yield attributes and energy in transplanted rice (Oryza sativa L.)
}

\author{
ISHRAT KHWAJA AND SAHAJADEVA
}

\begin{abstract}
The present investigation was carried out at research cum instructional farm, IGKV, Raipur, Chhattisgarh during Rabi season of 2011-12. There were twelve treatments comprised of pre and post- emergence application of different herbicide molecules either alone or in combination along with two hand weeding and unweeded check. Treatments comprised of AE $1887196-20$ per cent + AEF 095404- 10 per cent - 30 per cent WG, AE 1887196 - 20 per cent + AEF 095404 - 10 per cent - 30 per cent WG, AE 1887196 - 20 per cent + AEF $095404-$ 10 per cent -30 per cent WG, AE 1887196 -20 per cent SC, AEF 095404 -15 per cent WG, Butachlor 50 per cent EC, Pyrazosulfuran-ethyl 10 per cent WP, Pretilachlor 50 per cent EC, Fenoxaprop p-ethyl + Chlorimuron ethyl + Metsulfuron-methyl 20 per cent WP, Bispyribac-sodium 10 per cent SL, Two hand weeding, Unweeded check. Effective tillers per hill, panicle length, panicle weight, test weight, number of filled grains, grain yield and straw yield were highest under two hand weedings, whereas unweeded check recorded highest number of unfilled grains per panicle and sterility percentage.
\end{abstract}

KEY WORDS : Rice, Bio efficacy, Yield, Herbicides, Yield attributes

How to cite this Article : Khwaja, Ishrat and Deva, Sahaja (2014). Effect of new post emergence herbicides on yield and yield attributes and energy in transplanted rice (Oryza sativa L.). Internat. J. Forestry \& Crop Improv., 5 (2) : 73-78.

Article Chronical : Received : 28.08.2014; Revised : 05.11.2014; Accepted : 22.11.2014

\section{MEMBERS OF RESEARCH FORUM}

Address of the Correspondence :

SAHAJA DEVA, Department of Agronomy, Indira Gandhi Krishi

Vishwavidyalaya, RAIPUR(C.G.) INDIA

Email: sahajareddy.deva@gmail

Address of the Coopted Authors :

ISHRAT KHWAJA, Department of Agronomy, Indira Gandhi Krishi Vishwavidyalaya, RAIPUR(C.G.) INDIA 